\title{
Goal-setting and Self-reflection to Enhance Learners' Interaction in an ESP Context
}

\author{
Autorreflexión y formulación de objetivos para la \\ mejora de la interacción en estudiantes de inglés \\ para propósitos específicos
}

Sergio Andrés LOZANO VELANDIA

Universidad Minuto de Dios, Bogotá, Colombia

sergiolozano@uniminuto.edu

\begin{abstract}
This qualitative action research study explored the interactions of young-adult learners carrying out self-reflection on their learning processes in an ESP (English for special purposes) course at an airline training-center in Bogotá, Colombia. Needs analysis revealed that learners had poor knowledge of technical English, and lacked strong communicative and interactional competences, as well as self-reflection and goal-setting strategies. Accordingly, the pedagogical intervention focused on the use communicative tasks appropriate to their professional context (English for cabin crews) and the development of self-reflection strategies (practiced before and after each communicative task). Data collected through three stages using four instruments was analyzed with the grounded theory approach. Findings suggest that self-set goals and reflection helped learners focus on the specific language functions and vocabulary necessary to complete communicative tasks (role-plays) successfully, and that this led to increased learner awareness, confidence, and positive self-concept. In addition, learners showed progress in development of specific (ESP) language functions and technical vocabulary.
\end{abstract}

Keywords: English for specific purposes (ESP); self-reflection; goal-setting; communicative activities, CLIL.

\section{Resumen}

Este estudio cualitativo de investigación-acción exploró la interacción de estudiantes adultos jóvenes que llevaban a cabo autorreflexión sobre sus procesos de aprendizaje en un curso de inglés para propósitos específicos (ESP) en el centro de formación de una aerolínea en Bogotá, Colombia. Un análisis de necesidades evidenció que los estudiantes tuvieron un conocimiento deficiente de inglés técnico, y una carencia en competencias comunicativas e interactivas fuertes, además de estrategias de autorreflexión y formulación de objetivos de aprendizaje. Por consiguiente, la intervención pedagógica se enfocó en el uso de tareas comunicativas apropiadas para su contexto profesional (inglés para auxiliares de vuelo) y el desarrollo de estrategias de autorreflexión (practicadas al principio y al final de cada tarea comunicativa). Los datos recopilados en 3 etapas por medio de 4 instrumentos se analizaron por el muestreo teórico. Los resultados sugieren que la autoformulación de objetivos y autorreflexión ayudan a los estudiantes a que se concentren en las funciones del lenguaje específicas y en el vocabulario necesario para completar las tareas comunicativas (juegos de rol) con éxito y, a su vez, conducen a un aumento en la conciencia, la confianza, y el autoconcepto positivo de los estudiantes. Asimismo, los estudiantes evidenciaron avances en el desarrollo del lenguaje en cuanto a funciones comunicativas específicas y vocabulario técnico (ESP).

Palabras clave: inglés para propósitos específicos (ESP); autorreflexión; formulación de objetivos; actividades comunicativas.

Received: 2015-03-12 / Sent for peer review: 2015-03-13 / Accepted by peers: 2015-05-28 / Approved: 2015-06-05

To reference this article / Para citar este artículo

Lozano Velandia, S. A. (2015). Goal-setting and self-reflection to enhance learners' interaction in an ESP context. Latin American Journal of Content and Language Integrated Learning, 8(2), 131-160. doi:10.5294/lacli1.2015.8.2.4 


\section{INTRODUCTION}

Effective communication is perhaps the ultimate and most important goal of language. Although English is not the language spoken by most people around the world (Mandarin is), it is probably the language spoken across the greatest number of countries; it is a global language taken up by over seventy countries around the world (Crystal, 2003). Learners must be provided with real opportunities for learning; a need to communicate in English must be created in students, and chances to practice and interact with the language must be offered. Research provides opportunities to identify needs and/or problematic situations that may influence learners' language development, and this in turn can both foster the development of strategies to enhance learning and provide new insights on the ELT (English language teaching) field.

This study was carried out at the airline training center Escuela de Operaciones (a private context in Bogotá, Colombia) and emerged from the learners' difficulties in interacting effectively with passengers during the different phases of a flight. These difficulties could be attributed to the fact that students did not have opportunities to engage in relevant and meaningful classes in which they could use the language to talk about and simulate their daily routines at work. In order to join the airline's workforce, all flight attendants must have English competences related to general as well as technical English or specific English appropriate to assisting passengers on a flight. The participants were 11 flight attendant trainees, level A2 (according to the Common European Framework of Reference for Languages) and aged from 18 to 25 years old.

Throughout the semesters previous to the study, English-speaking passengers and crew members at the airline had filed complaints about poor interaction with cabin crew members on flights. At the training center, students also evidenced their interests and needs to strengthen their communicative competence in order to be able to communicate in the classroom and, eventually, at their workplace (on a passenger 
aircraft) once they started working. Nonetheless, the syllabus being implemented at the training center was still under development, and learners were never introduced to strategies, such as self-reflection on their language development, that might help them be more active participants in their learning.

\section{NEEDS ANALYSIS AND PROBLEM STATEMENT}

Learners' poor interactional competences and lack of metacognitive strategies were identified in a needs analysis, which took place in the students' first semester (in 2013). Alongside a record of the researchers' observations, a questionnaire was administered in which learners were asked about their feelings, opinions, and thoughts related to their reasons for studying English, its connection with their future jobs as flight attendants, and also the skills on which they believed they needed to work the most. A crosschecked revision and analysis of the data collected through both instruments (observation and questionnaire) was done using a color-coding procedure approach (Corbin \& Strauss, 2008). Students expressed that their main reason for studying English was their job and that they needed a better level of English to work in the airline company. They also thought that interaction with English-speaking passengers was "very important" or "essential". Finally, learners commented on their interest in learning technical vocabulary.

\section{RESEARCH QUESTION AND OBJECTIVES}

Accordingly, the research question posed was: How might a self-reflection strategy influence A2 (CEFR) young adult learners' interactions when participating in aviation-based communicative tasks? Correspondingly, the research objectives were to explore the influence that a selfreflection strategy has on learners' interaction when participating in aviation-based communicative activities, and to determine the way that goal-setting, as a component of the self-reflection strategy, may affect learner achievements. 


\section{THEORETICAL FRAMEWORK}

\section{English for specific purposes (ESP)}

English for specific purposes (ESP) refers to features related to English language instruction, from the point of view of the precise language (technical) that is needed in order for learners to succeed in their different disciplines and careers; ESP courses are tailored to specific needs (Hutchinson \& Waters, 1991). In this study's context, the learners, as cabin crew personnel, needed to interact more effectively with English speaking passengers. Belcher (2006) stressed the importance of carrying out needs analysis since ESP entails specific learners in specific contexts: "needs assessment is seen in ESP as the foundation on which all other decisions are, or should be, made" (Belcher, 2006, p. 135). In this particular research context, the trainee flight attendants have specific needs for specific contexts, confirmed by the researcher through his observations and supported by the learners' opinions. Richards (2006) illustrated the origins of ESP:

\footnotetext{
Many learners needed English in order to use it in specific occupational or educational settings. For them it would be more efficient to teach them the specific kinds of language and communicative skills needed for particular roles, (e.g., that of nurse, engineer, flight attendant, pilot, biologist, etc.) rather than just to concentrate on more general English. (p. 12)
}

Richards (2006) and Dudley-Evans and St John (1998) agree that ESP teaching is linked to a particular discipline or profession and makes use of a methodology that differs from that used in general-purpose English teaching, since many learners need English in order to use it in specific occupational or educational settings with specific roles (such as those of nurse, engineer, flight attendant, pilot, biologist).

There are few published studies on ESP in Colombia; there are a larger number of international studies. Among these, Dinçay (2011) conducted research on designing a learner-centered ESP course syllabus for administrative personnel in Turkey. He found that the situational- 
based ESP syllabus was the one that could suit the learners' needs the most. Based on situations, the teacher puts together real or imaginary scenarios in which language occurs or is used. These findings entail great responsibility from the teacher-researcher to choose the right scenarios for learners (e.g. boarding, onboard service, before takeoff). McDonough (2010) also touches on an aspect of ESP methodology, asserting that ESP success is crucially linked to the materials used based on learners' specific needs and contexts. He conducted an investigation on ESP materials for different professional areas in order to identify key components of ESP course books and courses, and found that there are no absolute rights and wrongs because what is important for teachers is whether a course meets learners' needs. Wood (2009) conducted a research on preparing American ESP learners for the workplace. This study concluded that formulaic sequences can help in the effective language training for specific situations by providing learners with a repertoire of language expressions and an awareness of the contexts in which they communicate. These finding all agree that simulations, along with a repertoire of expressions and language (such as a corpus), are key components of an ESP course when they are contextualized and relevant for ESP learners.

\section{Communicative language teaching (CLT)}

Linked to the previous construct, communicative activities are a specific factor of analysis framed into communicative language teaching (CLT), a functional approach to English teaching. Brown (2007) defined CLT in terms of 4 essential characteristics. First, goals are focused on various aspects, not only on grammatical or linguistic competences. Second, language techniques are meant to "engage students in authentic, functional and pragmatic use of language with meaningful purposes" (p. 241). This is reflected in learners making, for example, "safety requests" instead of learning what imperatives or modal verbs are. Third, fluency and accuracy are seen as complementary principles when communicating, where, at times, 
fluency has to take more importance than accuracy in order to keep learners engaged in language use. Finally, the fourth characteristic of CLT is that, in the communicative classroom, the ultimate goal is to use the target language in unrehearsed contexts.

In relation to this last observation, Harmer (2007) and Richards (2006) have highlighted that CLT activities typically involve students in real or realistic communication, where the successful achievement of their performed task is at least as important as the accuracy of their language use, which is not totally predictable. These points concerning real communicative contexts and unpredictability cannot be overemphasized. In the context of the present study, even though learners and future flight attendants need specific — and identifiable — language and vocabulary to interact on the plane with English-speaking passengers, they may also face completely unpredictable situations in their work.

A number of communicative activities suitable for use in the language classroom are task-completion activities (puzzles, games, map-reading), information-gathering activities, opinion-sharing activities, information-transfer activities, reasoning-gap activities, and role plays (Richards, 2006). The present study's instructional design is discussed further in the Method section.

\section{Task-based language learning}

Task-based language learning (TBL) is a language learning method that lies under the wider umbrella of the CLT methodology. TBL was used in the present study to engage learners in communicative tasks during the pedagogical intervention. Communicative tasks are defined by Nunan (1989) as pieces of classroom work that involve learners in comprehending, manipulating, producing, or interacting in the target language while their attention is mainly focused on meaning rather than form. Willis (1996) identified the "pre-task", "task cycle" and "language focus" as the stages of the whole task. The "pre-task" introduces learners to the topic and the main task as such. The "task cycle" offers learners chances to use the language in order to carry 
out the task (simulation, role-play) and improve that language under the teacher's guidance (Willis, 1996). The last stage, "language focus", allows a closer study of some specific features that occur naturally in the language used during the "task cycle". A deeper description of how in the present study tasks were carried out during the intervention is provided in the Method section.

\section{Self-monitoring}

Self-monitoring refers to a set of language-learning strategies that students can learn and implement as part of an autonomous learning process. Learning strategies are specific actions, behaviors, steps, or techniques to tackle a difficult language task used by students to enhance their own learning (Scarcella and Oxford 1992). Oxford (1990) also defines "Language Learning Strategies" as techniques implemented by learners to increase their knowledge, understanding, and use a second or foreign language while also increasing their independence and autonomy in the learning process. Oxford (1990, 2011 ) provides 6 major groups of strategies: cognitive, metacognitive, memory-related, compensatory, affective, and social. From these six groups, self-monitoring belongs to the metacognitive strategies group, since assessing and monitoring oneself in learning an L2 (second language) entails reflecting upon and evaluating one's learning process (Oxford, 1990; O’Malley \& Chamot, 1990).

Schunk (2002) argues that goal-setting involves establishing a standard or objective to serve as the aim of one's actions and occurs at several different points in a goal-achievement process: forethought (setting goals), performance control (monitoring), and self-reflection (evaluating goal progress). The benefits of goal-setting for learners can include enhanced focus on the task, exertion of the effort necessary to meet the task demands, and improve self-efficacy when goals are attained. Schunk (2002) additionally points out 3 properties that learner goals must have to be successful. The first property is specificity (goals need to incorporate specific performance indicators); the 
second is proximity (goals need to be specific as to how far they project into the future); and the third is difficulty. In terms of learner training for self-set goals, Schunk (2002) stresses that learners may need to be provided with both the goals and goal-setting strategies simultaneously.

In this study, learners carried out self-reflection after performing the tasks, expressing their ideas, opinions, and feelings with regard to their self-set goal attainment. Hurd and Lewis (2008) stressed the importance of allowing learners time and space for reflection, as well as the production of spontaneous writing through unstructured journals or logs. They also stressed that learners may find it difficult to put their feelings into words, and sometimes their repertoire in the target language may be insufficient. Accordingly, in the present study, learners were given the choice of writing their reflections in Spanish, English, or both, depending on with what they felt comfortable. The strategy planned, taught, and implemented was a reflective learning sheet (Harris \& McCann, 1994) on which learners could write down information such as what went on in class, what they felt they had learned, what problems they had, and what they were going to do to overcome these.

Sanchez (2012) has explored the impact of self-monitoring strategies on A1 learners in a blended learning environment in Colombia, finding that the participants increased their awareness of the language-learning process despite the fact that they were not required to show these achievements. She also noted that the participants developed self-regulated learning capabilities to an extent, but also experienced some difficulty when dealing with time management and the demands of the blended course in which they were studying. Wallace (2012) explored the language learning strategies used by Spanish adults when engaging in communicative tasks in a business context, finding that they used metacognitive strategies consistently in all business communication tasks. They also recognized the importance and use of English not only in their work environment but also in other aspects of their lives. This suggests that the use of metacognitive 
strategies can prompt learners to discover and explore areas beyond the technical English they need to carry out specific communicative tasks in their workplaces. Förster and Souvignier (2014) studied goalsetting and its effects on reading with students from Munster, Germany. The experimental group experienced significantly greater improvements in reading than did the control group; however, although success was defined by reaching or exceeding the self-set goal, it was also found that students sometimes misinterpreted exceeding a goal as failure. This interesting, unexpected finding reflects the importance of training and sensitizing learners to the purpose of self-set goals. Chimentão and Aparecida de Souza (2013) carried out a research study that analyzed learners' self-regulation practices when planning their own actions and strategies, concluding that planning and monitoring one's own learning process is an effective part of self-assessment only if joined to teacher intervention and motivational strategies, which supports Förster and Souvignier's (2014) results. Based on these studies, it seems that in general terms self-monitoring strategies (like those used in the present study, such as goal-setting and self-reflection) may need a significant amount of teacher intervention, support, and additional motivational strategies to be successful.

\section{METHOD}

\section{Research design}

\section{Type of study, context, participants}

The present study was conducted as qualitative action research (AR), which relates to the ideas of "teacher as researcher" (Burns, 2010). In this case, the teacher-researcher was involved in a "reflective practice" (observing while teaching) that ultimately sought the implementation of an action plan based on a problematic situation or a needs analysis. Thus, the teacher-participant became an explorer of his own teaching context and realities. Burns (2010) also characterizes AR as smallscaled and contextualized within a specific social situation, school, 
or classroom; in this case, the study was contextualized and framed within a class of 11 students being taught Aviation English at an airline training center. Burns (2010) also notes that, "the central idea of the action part of AR is to intervene in a deliberate way in the problematic situation in order to bring about changes and improvements in practice” (p. 2). The current study sought to enhance students' interactional abilities while taking part in ESP communicative activities, as well as their command of goal-setting and self-reflection strategies. There are four main components of AR, which form a cycle: planning, actions, observation, and reflection (Burns, 2010).

The present study took place at the airline training-center Escuela de Operaciones, a private school belonging to the leading airline in Colombia. At the training center, trainee flight attendants study English for 4 months using a communicative approach. The learners also study various content subjects in Spanish, including emergency procedures, in-flight service, and customer service procedures. Their English lessons are taught in 5 face-to-face sessions weekly, each class lasting 2 hours and 15 minutes.

The participants of this study were 11 students with CEFR level A2, 1 man and 10 women, aged 18 to 25 years old. They came from different regions of Colombia and were attending a course designed to improve their English over the period of 1 year. Prior to this study, classes had been somewhat related to the learners' specific needs, but little or no room had been set apart for students to learn in an autonomous way or reflect upon their learning.

Data collection instruments and procedures.

The data collection instruments used in the present study were narrative observation field notes, questionnaires, classroom documents, and audio recordings (Burns, 2010; Cohen et al., 2007). The data collection procedures comprised two main stages. The first stage was "pre-planning", which took place in the first semester of 2013 and included the needs analysis (see the Needs analysis and 
problem statement section), identification of the principal problem (learner's lack of interaction), and formulation of the research question (see the Research question and objectives section). The second stage, the "while stage", included the development and implementation of data collection procedures, including both the piloting of the instruments and the data collection stages as such during the pedagogical intervention. As the implementation progressed, 3 stages of data collection took place during which 4 data collection instruments were applied (for details, see Appendix A: Research design and pedagogical implementation).

Pedagogical implementation

The data gathered from the needs analysis demonstrated a need for a meaningful, contextualized communicative language teaching lessons. A pedagogical intervention that combined technical aviation English with meaningful communicative activities along with a self-reflection strategy was designed to enhance learners' communicative skills and interaction while encouraging them to become more autonomous and responsible for their language development.

\section{Vision of language, learning and curriculum}

The vision of language and learning is, hence, narrowed down to ESP; the focus of classroom sessions shifted from "general" to technical and functional English. The CLT methodology selected to help students learn this functional language stresses the importance of having students practice the language for real, communicative, contextualized purposes (Brown 2007). In this study, language was seen as a means for students to accomplish specific functions, such as offering meals, making safety announcements, or providing passengers with other information related to a flight. Harmer (2004) asserts that the study of functions in language has a profound effect upon the design of language teaching materials, making language purpose a major factor in the choice of syllabus items and teaching techniques. Hutchinson 
and Waters (1991) argue that ESP is an approach to language learning based on learner needs; the foundation of ESP is the simple question, "Why does this learner need to learn a foreign language?". For the present study, the answer to that question, which narrows the vision of language and learning down to a functional approach, was: the learners need English to communicate with non-Spanish-speaking passengers on the airplane. Regarding the curriculum, it is important to note that the contents and functions studied by the trainee flight attendants were aligned to the contents they study in their mother tongue at the operations school (such as services on-board, safety and security, procedures) and scenarios in which learners would need to interact with passengers using different functions in English.

Instructional design

The pedagogical implementation took place over a total of 15 sessions, each consisting of a 2-hour and 15-minute class; the total time allotted to the implementation was 34 hours. The sessions were framed within the CLT methodology, task-based language-learning, and goal-setting principles. This implementation was aimed at promoting learner interaction and the use of spoken English in the classroom for different communicative tasks/activities that integrated ESP (English for cabin crew), including language functions such as giving directions, making requests, or offering products.

\section{Methodology and lessons}

Sessions were planned around the concepts of task-based language learning (Nunan, 1989; Willis, 1996). Communicative tasks are defined by Nunan (1989) as pieces of classroom work that involve learners in comprehending, manipulating, producing, or interacting in the target language while their attention is mainly focused on meaning rather than form. Learners' final communicative task for a unit or session consisted of a simulation or role-play that represented common situations onboard airplanes in which flight attendants need 
to interact and convey meaning through the use of certain language functions. Willis (1996) argues that the advantages of developing a communicative task in pairs or groups include added learner confidence in trying out whatever language they know without fear of being wrong or corrected, thereby enhancing spontaneous interaction, negotiation, and meaning building.

Willis (1996) identifies the "pre-task", "task cycle" and "language focus" as the stages of a whole task (see the Task-based language learning section). In the "pre-task" stage, at the beginning of a session, learners used a self-reflection sheet to write down their self-set goals based on criteria on which they had previously received training. However, after collecting the first set of reflection sheets, it was noted that learners were having difficulties in adhering to the characteristics of the objectives (proximal, time-based, and moderately difficult); therefore, a second session for re-training on goal-setting was implemented during data collection stage 1. After learners wrote down their goals and some further input was given ("pre-task"), learners usually prepared their tasks through learner-centered, communicative groupor pair-work activities. They studied the specific language functions for the session (for example, making requests) and, finally, prepared a role-play or simulation in groups that represented a real situation. This role-play or simulation task formed the core of the "task cycle"; during it, the teacher monitored progress, resolved doubts, and took field notes. After feedback from the teacher, students performed the final stage of "language focus", in which they were intended to think about the language they had used, reflect upon possible difficulties, and record their observations on the same reflection sheet on which they had originally written their goals. As lessons progressed, learners gained some mastery in the use of the reflection sheets. The Appendix: Research design and pedagogical implementation section summarizes the overall process. 


\section{DATA ANALYSIS METHOD AND PROCEDURES}

\section{Data management and condensation}

Data was gathered through physical and printed material in the form of questionnaires, self-reflection sheets, teacher's field notes, and recorded files for the learners' final speaking exam, and filed in a physical folder (Stage 1, Stage 2, and Stage 3). Afterwards, data was organized in Microsoft Excel charts. Data was reduced, or condensed, throughout the process by selecting, focusing, simplifying, abstracting and/or transforming the data that appeared in the full corpus of data collected (Miles et al., 2014). Table 1 provides a example of how data was condensed.

\section{Table 1. Data condensation sample from Questionnaire 2, Question 2}

\begin{tabular}{|c|c|c|}
\hline Question & Student & Segment \\
\hline \multicolumn{3}{|r|}{ Question 2} \\
\hline \multirow{11}{*}{$\begin{array}{l}\text { What happens } \\
\text { when you } \\
\text { formulate your } \\
\text { own goals for } \\
\text { the different } \\
\text { language } \\
\text { tasks? }\end{array}$} & A & $\begin{array}{l}\text { "tengo una meta clara y me enfoco en cumplirla en cada clase } \\
(\ldots) \text { " }\end{array}$ \\
\hline & B & $\begin{array}{l}\text { "el problema es que no soy autodidacta en clases las hago } \\
\text { pero salgo y no estudio }\end{array}$ \\
\hline & $\mathrm{C}$ & $\begin{array}{l}\text { "Is easier to keep the focus to the want to achieve and more } \\
\text { easy to get it" }\end{array}$ \\
\hline & $\mathrm{D}$ & $\begin{array}{l}\text { "cuando formulo mis propios objetivos busco la manera de } \\
\text { alcanzarlos" }\end{array}$ \\
\hline & $\mathrm{E}$ & $\begin{array}{l}\text { "Sometimes I finish for completed my goals and I feel so good } \\
\text { when I realized that I achive my goals (...)" }\end{array}$ \\
\hline & $\mathrm{F}$ & $\begin{array}{l}\text { "De esta manera se cuales son mis metas y hacia donde debo } \\
\text { llegar y cómo podré hacerlo" }\end{array}$ \\
\hline & G & "I have better challenges about the language. I try to get them." \\
\hline & $\mathrm{H}$ & $\begin{array}{l}\text { "asi nosotros estamos mucho mas pendientes de alcanzar las } \\
\text { metas propuestas." }\end{array}$ \\
\hline & 1 & $\begin{array}{l}\text { "aprendo más porque me pongo a reflexionar en qué tanto } \\
\text { estoy poniendo de mi parte para mi propio aprendizaje (...) } \\
\text { me preocupo por algo especifico y asi aprendo mas" }\end{array}$ \\
\hline & $\mathrm{J}$ & "I feel that I'Il do it. It's easier to achieve" \\
\hline & $\mathrm{K}$ & $\begin{array}{l}\text { cuando formulo mis objetivos intento realizar o hacer énfasis } \\
\text { por medio de las actividades en las habilidadesque debo } \\
\text { mejorar. }\end{array}$ \\
\hline
\end{tabular}




\section{Data validation}

Data was validated through application of the "constant comparative procedure" (Creswell, 2012; Corbin \& Strauss, 2008, Cohen et al., 2007), in which different sources of data were triangulated in order to confirm and retrieve evidence from two or more instruments (see Table 2).

Table 2. Instruments triangulated for the different categories

\begin{tabular}{|c|c|}
\hline Categories & Instruments triangulated \\
\hline Awareness increase & Questionnaire \# 2, Self-reflection sheet \\
\hline Goals to stay focused & Teacher's field notes, Questionnaire \#2 \\
\hline $\begin{array}{c}\text { Confidence and self-concept } \\
\text { building }\end{array}$ & Self-reflection sheets, Questionnaire \#2 \\
\hline Interaction improvement & Questionnaire \#3, Audio recording \\
\hline
\end{tabular}

\section{Data analysis and coding procedures}

Data analysis was performed through the grounded theory approach (Creswell, 2012; Corbin \& Strauss, 2008; Cohen, Manion, \& Morrison, 2007), in which systematic procedures of collecting data, identifying categories, and connecting these categories, allows the formation of a theory that explains the observed process. In following this approach, data was coded - a process of disassembling and reassembling the data to produce a new und that explores similarities and differences across a number of different cases - in accordance with the 3 types of coding used in grounded theory: open, axial, and selective (Corbin \& Strauss, 2008; Cohen et al., 2007). Open coding was carried out with data from each of the instruments; segments were extracted (data condensation), and similar responses or insights were given "codes" which then became preliminary categories. Table 3 provides a sample of the open coding procedure.

Thereafter, axial coding was used making links between categories (Cohen et al., 2007; Creswell, 2012); Figure 1 shows the interrelationships that emerged from data analysis between the core category 
Table 3. Open coding sample from questionnaire 2 , question 4

\begin{tabular}{|c|c|c|c|c|}
\hline Question & Student & Segment & Codes & Categories \\
\hline \multicolumn{5}{|c|}{ Question 4} \\
\hline \multirow{11}{*}{$\begin{array}{l}\text { What happens } \\
\text { when you } \\
\text { reflect on } \\
\text { your goals, } \\
\text { achievements } \\
\text { and } \\
\text { difficulties } \\
\text { after a } \\
\text { lesson? }\end{array}$} & A & $\begin{array}{l}\text { Me doy cuenta que si marco } \\
\text { mis objetivos los alcanzo más } \\
\text { rápido }\end{array}$ & awareness & \multirow{11}{*}{$\begin{array}{l}\text { positive } \\
\text { feelings }\end{array}$} \\
\hline & B & $\begin{array}{l}\text { Me doy cuenta que tengo y } \\
\text { debo estudiar en mi casa. No } \\
\text { solo en la escuela }\end{array}$ & awareness & \\
\hline & C & $\begin{array}{l}\text { I understand that I have to } \\
\text { learn and practice more. The } \\
\text { learning is a constant process }\end{array}$ & awareness & \\
\hline & $\mathrm{D}$ & $\begin{array}{l}\text { Lleva a exigirme mucho más, } \\
\text { a buscar la forma mas practica } \\
\text { de aprender y mejorar. }\end{array}$ & $\begin{array}{l}\text { learning and } \\
\text { improvement }\end{array}$ & \\
\hline & $\mathrm{E}$ & $\begin{array}{l}\text { I realize for myself what } \\
\text { things about the English class } \\
\text { I need to reinforce to improve } \\
\text { in my english class and my } \\
\text { autonomous learning }\end{array}$ & & \\
\hline & $\mathrm{F}$ & $\begin{array}{c}\text { Me preocupo por corregir } \\
\text { en mis dificultades y trato } \\
\text { de aplicar lo aprendido en } \\
\text { future. }\end{array}$ & $\begin{array}{c}\text { correction } \\
\text { àd. } \\
\text { improvement }\end{array}$ & \\
\hline & G & $\begin{array}{l}\text { Depend, if the situation is } \\
\text { positive, I feel good, but when } \\
\text { it is negative I try to look for } \\
\text { an option to better }\end{array}$ & & \\
\hline & $\mathrm{H}$ & $\begin{array}{c}\text { Que puedo estar mucho mas } \\
\text { segura de que es lo que tengo } \\
\text { que mejorar. }\end{array}$ & awareness & \\
\hline & I & $\begin{array}{l}\text { Pienso en qué tanto realizé } \\
\text { por el cumplimiento de } \\
\text { mis objetivos, qué tanta } \\
\text { honestidad tengo conmigo } \\
\text { misma y mi tiempo. }\end{array}$ & $\begin{array}{c}\text { learning } \\
\text { achievement }\end{array}$ & \\
\hline & $J$ & $\begin{array}{l}\text { I have more enthusiasm with } \\
\text { the items I have difficulties. }\end{array}$ & challenge & \\
\hline & $\mathrm{K}$ & $\begin{array}{c}\text { Cuando reflexiono identifico } \\
\text { las posibilidades dificultades } \\
\text { para mejorar." }\end{array}$ & awareness & \\
\hline
\end{tabular}

and other categories. Finally, selective coding produced a theory (see the Results and Discussion sections) from the interrelationship of the categories in the axial coding model (Creswell, 2012). 


\section{RESULTS}

Analysis of the data collected in the present study, which explored the effect of a self-reflection strategy on learners' interaction when taking part in ESP communicative tasks, revealed 3 main categories: goals to stay focused (core category), awareness increase, and confidence and self-concept building. Two subcategories, interaction improvement and attainment of specific goals, were also identified. Figure 1 shows the core category and its relationships to the other categories.

Figure 1. Coding paradigm: interrelationships between the core category and other categories and sub-categories

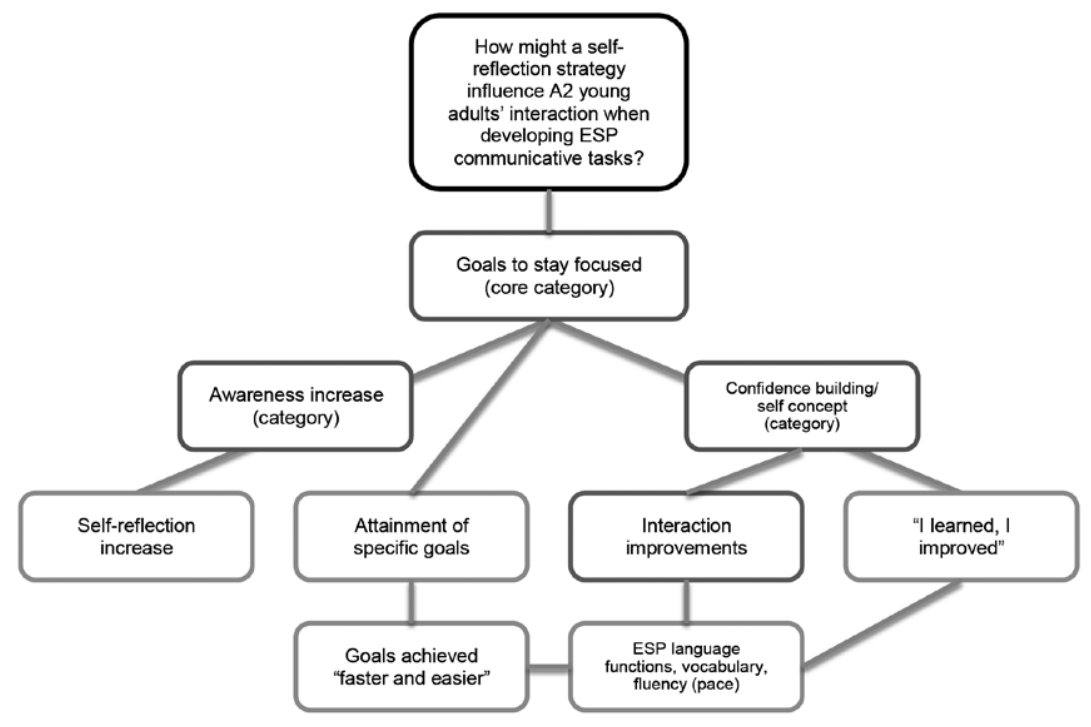

\section{CATEGORIES}

\section{Core category 1: Goals to stay focused}

The core category found through data analysis was goals to stay focused. As mentioned previously, learners were trained (and re-trained) to set their goals based on the criteria of specificity, proximity, and difficulty proposed by Schunk (2002). Figure 2 and Figure 3 provide an example of how a sample of how a given student's goals became more specific after training. 
Figure 2. Student goal-setting process after first training

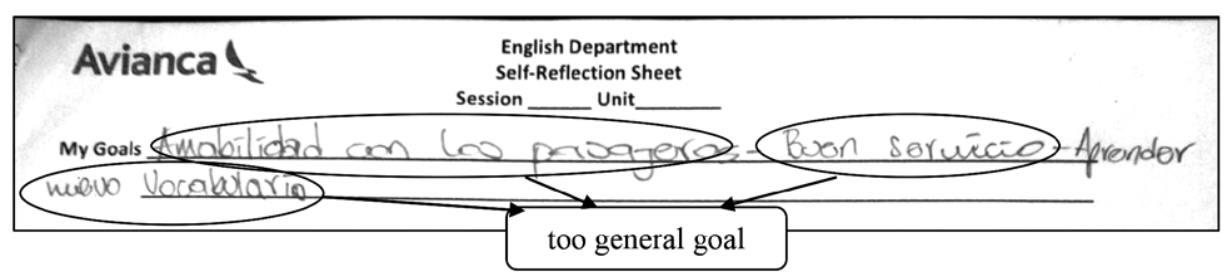

Figure 3. Student goal-setting process after re-training

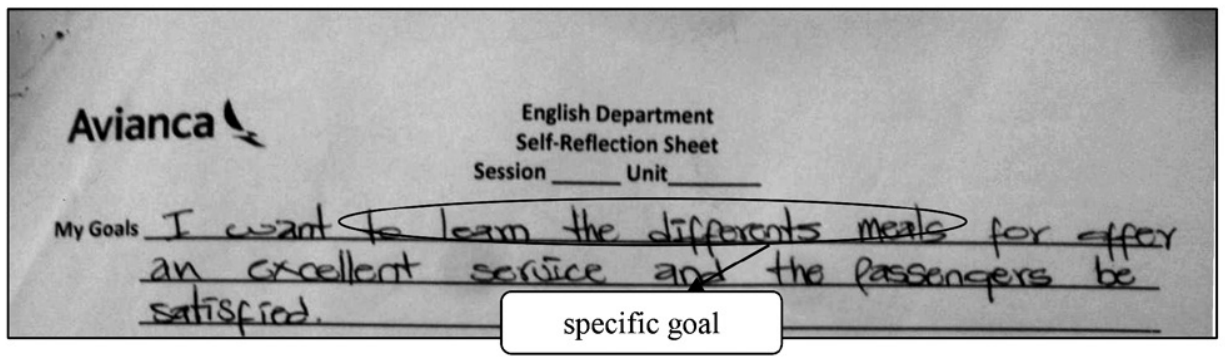

The results also suggest that when learners set goals, they were better able to focus on them, pointing out and narrowing down what they wanted to learn or improve. Excerpt 1, Excerpt 2, and Excerpt 3 provide examples of how learners were able to use goals to stay focused.

\section{Excerpt 1. Reflection sheet, Student D}

"My goals: more fluence and vocabulary, excellent service on board, good modals."

\section{Excerpt 2. Questionnaire 2, Student E}

"Ha sido una gran experience (...) me parece una forma ordenada de lograr unos objetivos propuestos por mí y realmente alcanzables en cuanto al aprendizaje del inglés en mi campo laboral"

Excerpt 3. Teacher's field note 2, September 30

"everyone has done a great job in this class focusing on their down-to-earth and specific objectives" 
Schunk (2002) argues that goals direct individuals' attention to relevant task features, behaviors to be performed, and potential outcomes. The results of the present study suggest that the learners' self-set goals improved in terms of specificity, proximity and being time-based as more training and practice was provided. This ultimately resulted in benefits to learners' language interaction, since learners focused on specific language functions, studied them, and then used them during the simulations. These benefits were identified in the subcategory specific goal attainment, from which some examples are shown in Excerpt 4 and Excerpt 5.

\section{Excerpt 4. Questionnaire 3, Student K}

Yes. Porque he aprendido nuevo vocabulario y nuevas expresiones que me hacen sentir segura y así tener fluidez en el idioma.

Excerpt 5. Questionnaire 2, Student J

"I feel that l'll do it. It's easier to achieve"

\section{Category 2: Awareness increase}

The data also suggest that learners became more aware of their learning processes thanks to the goals they set for each unit and the reflections they made after each oral performance. Learners seemed to become more sensitized to what they needed to learn and their respective strengths and weaknesses, as illustrated in Excerpt 6, Excerpt 7, and Excerpt 8.

\section{Excerpt 6. Questionnaire 2, Student E}

"I realize for myself what things about the english class I need to reinforce for improve in my english class and my autonomous learning." 


\section{Excerpt 7. Questionnaire 2, Student H}

"I reflect many times. Because esto me ayuda a estar consciente de mi avance y de mis falencias."

\section{Excerpt 8. Reflection sheet, Student D}

“The few vocabulary makes I can't have a fluid English"

Undoubtedly, an increase in awareness about the learning process after setting their goals and reflecting on them represent major steps towards becoming autonomous learners. This awareness increase also entailed the learners' putting more effort into setting specific and reachable goals, as well as in attaining these.

\section{Category 3: confidence building and self-concept}

The results also suggest that when learners developed goal-setting and self-reflection practices, this influenced their emotional states (based on goal-attainment and reflection). As part of a process influenced by their goal-setting and reflection practices, learners not only expressed their perceptions on their achievements and language development, but they also evidenced confidence building and positive self-concept to some extent, as exemplified in Excerpt 9, Excerpt 10, and Excerpt 11.

\section{Excerpt 9. Reflection sheet, Student J}

"I feel that I have learned a lot not only for the class, if not for our lives".

Excerpt 10. Questionnaire 2, Student E

"Sometimes I finish for completed my goals and I feel so good when I realized that I achive my goals (...)"

Excerpt 11. Reflection sheet, Student C

"I am happy for to learn more about this job in the plane" 
The findings further suggest that learners' positive feelings based on their goal attainment and reflections may have increased their self-efficacy, which is a context-related judgment of personal ability to organize and execute course of action to attain certain levels of performance (Zimmerman, 2002; Bandura, 1995). Unfortunately, an in-depth exploration into learners' self-efficacy was not possible due to time constraints.

\section{Sub-category: interaction improvement}

Results also provided evidence of learner progress in terms of adequately paced, accurate interactions between learners and "passengers" in simulated but realistic scenarios in their daily role-plays and final speaking exam. The processes of self-reflection and goal-setting seemed to help learners to stay focused and become more aware of their difficulties and needs, as well as to consciously practice the relevant language when speaking, as exemplified in Excerpt 12, Excerpt 13, and Excerpt 14.

\section{Excerpt 12. Questionnaire 2, Student K}

"porque he aprendido nuevo vocabulario y nuevas expresiones que me hacen sentir segura y así tener fluidez en el idioma"

\section{Excerpt 13. Researcher reflection on audio recordings}

"The majority of learners evidenced development of language communicative skills, enhancing their interaction in terms of using language functions (apologizing, offering, requesting, giving directions) and technical vocabulary. Although learners evidenced error making with grammar structures, most of them mastered technical vocabulary of the plane and language functions (...)"

Excerpt 14. Questionnaire 2, Student B

because I speak more, and the activities give me more confidence" 
Learners also expressed their interests in learning vocabulary for their specific context and, although this was not the main research focus, it was found that many of them set goals focused on vocabulary learning, which contributed positively to interaction in terms of adequate speaking pace and accuracy. Excerpt 15, Excerpt 16, and Excerpt 17 provide some samples of how learners discussed (in Excerpt 15 from a self-reflection sheet) their desires to learn more vocabulary, their opinions of what they had learned (in Excerpt 16 from a questionnaire responses), and their actual spoken interaction (in Excerpt 17 from an audio recording transcript).

\section{Excerpt 15. Reflection sheet, Student $\mathrm{H}$}

"my goals: know about meal's vocabulary to improve my fluency, pronunciacion and my service on board"

\section{Excerpt 16. Questionnaire 2, Student H}

"porque las clases nos ayudan mucho a practicar y a realmente aprender más vocabulario"

\section{Excerpt 17. Audio recording of Student E with technical vocabulary highlighted}

Passenger: Excuse me lady!

Student E: Yes, can I help you?

P: Yeah lock. Um ... I'm trying to fit my bag in the overhead bins as you said, but it doesn't fit, I don't [know]

S: [ok] I am afraid that it won't fit in the overhead compartments

P: oh my [God]

S: [It's] oversized

P: But they didn't tell me that in the counters.

S: yeh, if you want, you can try. If the hand luggage ... fit, you can keep the baggage, but if not we have to send the hand baggage to the cargo compartment. P: yeh, I already tried and it didn't fit, I am sorry. You said cargo compartment, but I have my laptop and [my]

S: [please] take it ... out. Give me your hand luggage and I will go ... I will ... give you a bag tag to reclaim your luggage at the airport, at the baggage claim area. 


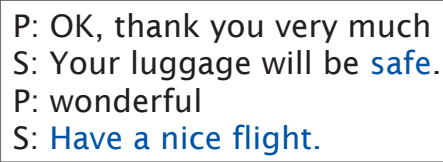

\section{DISCUSSION}

Through the data analysis process, the present study's research question (see Research question and objectives) was answered through the identification of 3 categories in the data that together showed how the learners were progressing in their initial steps towards the mastery of self-reflection and goal-setting. It is concluded that selfset goals and reflection allowed learners to maintain the focus on the specific language functions and vocabulary necessary for them to interact successfully during the communicative tasks (role-plays) and, in turn, that this led to an increase in learner awareness. Confidence building and positive self-concept also emerged as a result of tangible goal attainment encouraged by those practices. In addition, learners further developed their language in terms of specific (ESP) language functions and technical vocabulary, thereby enhancing their interactions. These findings regarding learner awareness are similar to those of Sánchez (2012) who explored the impact of self-monitoring strategies on the learning experience of $\mathrm{A} 1$ learners in a blended learning environment in Colombia. She found that the participants increased their awareness of the language process, despite the fact they were not required to evidence their achievements.

Förster and Souvignier (2014) studied goal-setting and its effects on reading achievement, reading motivation, and reading selfconcept with students in Münster, Germany in both an experimental and a control group. In alignment with the present study's findings on learner progress, they found that their experimental group enjoyed significantly greater improvements in reading than the control group. However, although they defined success as reaching or exceeding the self-set goal, the students' reflection sheets indicated that students 
sometimes misinterpreted exceeding a goal as failure; often, only the achievement of the exact goal set was interpreted as a "success", leading to frequent experiences of "failure". Similarly, the present study found that its participants needed extra training on and sensitization to the effective use of the reflection sheet, as well as their own goal-setting, to ensure they followed the criteria of specificity, proximity, and difficulty (Schunk 2002). This suggests that results may vary if more time were allotted for systematic training on the strategy, which might result in new insights related to learners' motivation and enhanced goal commitment as results of effective goal-setting (Schunk, 2002), not to mention their development with regard to technical vocabulary and language functions.

In terms of the pertinence of the current study, there are two aspects to be considered. Firstly, this study represents innovation in the local context: learners had never been trained on goal-setting and/or self-reflection, abilities that align with a student-centered pedagogical philosophy that seeks to meet learners' language needs (despite the challenges and limitations that can be encountered when training learners in unfamiliar strategies). Secondly, there have been few prior studies in the field of ESP in similar private Colombian contexts. Thus, the conclusions found in this specific private context should be further explored elsewhere.

\section{Pedagogical Implications}

As suggested by the findings, the inclusion of training in self-reflection strategies along with learner-centered communicative tasks can provide marked benefits to learners' language development. Goalsetting, as part of the learners' self-reflection strategy, helps learners self-set their goals and stay focused on them. An unexpected (that is, not directly related to learner speaking, interaction, or fluency) but interesting additional finding was that many of the learners' goals aimed at learning additional technical vocabulary, rather than (for example) improving fluency or learning new expressions. In relation to 
this, Sanchez (2013) has argued that self-monitoring might promote vocabulary learning - and, as a matter of fact, at the end of the current study, learners did show (in audio recordings from their final exams) significant gains in technical vocabulary and aviation terminology. They were able to incorporate these into their speech, resulting in better interaction in terms of faster pace and better accuracy.

Certainly, in light of the present study's findings, it is recommended that the airline's language-learning curriculum and syllabus be revised to include training in self-monitoring strategies as part of ESP lessons. Nevertheless, further research on self-monitoring strategies and goalsetting could provide additional insights on how to continue improving these kinds of training and implementation processes. It is important for future teacher-researchers to plan piloting and training stages for the main strategies to be taught, and to plan the allotment of training time carefully to help learners to understand and internalize the strategies to make the best of their experiences.

\section{Limitations}

The study did not include a technical vocabulary and language functions corpus that could have aided in tracking learners' language development (especially in terms of technical vocabulary and language functions). Similarly, a study on preparing American ESP learners for the workplace by Wood (2009), who used a set of simulations related to the types of speech these engineering learners would find at their jobs, found that a repertoire (corpus) of expressions and language (when contextualized and relevant to the ESP context) can enhance language learning.

\section{Further Research}

Given the finding that learners identified the learning of technical vocabulary learning as a key language development interest, a study on exploring goal-setting and self-monitoring strategies in an ESP 
context, using a vocabulary corpus (see the Limitations section) to track vocabulary learning could be fruitful. In such a case, "measuring" learner achievements in relation to their own self-efficacy concepts (Bandura, 1995) and motivation indicators should be possible.

Finally, in alignment with contemporary educational trends, it would be valuable to explore vocabulary learning in blended ESP learning courses, using Web-based tools for instructional and data collection purposes, as student carried out self-monitoring. A particular focus in this area could be learner attitudes and motivational indicators regarding the blended learning environment as well as their self-assessment/monitoring processes.

\section{CONCLUSIONS}

This study has revealed useful insights into the use of goal-setting and reflection by CEFR A2-level young-adult learners in carrying out communicative ESP tasks. Its findings should be transferable to the contexts of other airlines worldwide, where English is learned as a foreign language (EFL) and learners have similar profiles. Overall, the present conclusions and recommendations should be broadly applicable in many similar contexts, where learners' language levels have a direct impact on their job performance (in this case, as flight attendants in the private airline industry), mediated by other variables such as age and the extent to which learners may arrive to training with initially poor reflection strategies. Indeed, the current study's results should be transferable to other local ESP contexts - not only in Colombia, but wherever English is required to enter and succeed in a company's workforce.

\section{ACKNOWLEDGEMENTS}

This paper is based on a presentation at the 5th Biennial CLIL Symposium: New trends, challenges, and opportunities in the CLIL classroom, Universidad de La Sabana, Chía, Colombia, 12 September 2014. 


\section{REFERENCES}

Bandura, A. (1995). Self-efficacy in changing societies. Cambridge, UK: Cambridge University Press.

Belcher, D. D. (2006). English for specific purposes: Teaching to perceived needs and imagined futures in worlds of work, study and everyday life. TESOL Quarterly, 40(1), 133-151.

Brown, H. D. (2007). Principles of language learning and teaching $\left(5^{\text {th }}\right.$ ed.). White Plains, NY: Pearson Longman.

Burns, A. (2010). Doing action research in English language teaching: A guide for practitioners. New York, NY: Routledge.

Chimentão, G., \& Aparecida de Souza, N. (2013). Self-regulation in the learning process: Actions through self-assessment activities with Brazilian students. International Education Studies, 6(10), 47-62.

Cohen, L., Manion, L., \& Morrison, K. (2007). Research methods in education ( $6^{\text {th }}$ ed.). London, UK: Routledge.

Corbin, J., \& Strauss, A. (2008). Basics of qualitative research: Techniques and procedures for developing grounded theory ( $3^{\text {rd }} \mathrm{ed}$.). Thousand Oaks, CA: Sage.

Creswell, J. (2012). Educational research: Planning, conducting and evaluating quantitative and qualitative research ( $4^{\text {th }} \mathrm{ed}$.). Boston, MA: Pearson Education.

Crystal, D. (2003). English as a global language (2 $\left.{ }^{\text {nd }} \mathrm{ed}.\right)$. Cambridge, UK: Cambridge University Press.

Dinçay, T. (2011). Designing a learner-centered ESP course for adults and incorporating the learners' aims into a situational-based syllabus. Ekev Academic Review, 15(49), 235-247.

Dudley-Evans, T., \& St John, M. J. (1998). Developments in English for specific purposes. Cambridge, UK: Cambridge University Press.

Förster, N., \& Souvignier, E. (2014). Learning progress assessment and goal-setting: Effects on reading achievement, reading motivation and reading self-concept. Learning and Instruction, 32, 91-100. 
Harmer, J. (2004). How to teach writing. White Plains, NY: Pearson Longman.

Harmer, J. (2007). The practice of English language teaching ( $\left.4^{\text {th }} \mathrm{ed}.\right)$. White Plains, NY: Pearson Longman.

Harris, M., \& McCann, P. (1994). Assessment. Oxford, UK: Heinemann. Hurd, S., \& Lewis, T. (2008). Language learning strategies in independent settings. Bristol, UK: Multilingual Matters.

Hutchinson, T., \& Waters, A. (1991). English for specific purposes: A learning-centred approach. Oxford, UK: Oxford University Press. McDonough,J. (2010). English for specific purposes: A survey review of current materials. ELT Journal, 64(4), 462-477.

Miles, M. B., Huberman, M., \& Saldaña, J. (2014). Qualitative data analysis: A methods sourcebook ( $3^{\text {rd }}$ ed.). Thousand Oaks, CA: Sage.

Moeller, A., Theiler, J., \& Wu, C. (2012). Goal setting and student achievement: A longitudinal study. The Modern Language Journal, 96, 153-169.

Nunan, D. (1989). Designing tasks for the communicative classroom. Cambridge, UK: Cambridge University Press.

O'Malley, J. M., \& Chamot, A. U. (1990). Learning strategies in second language acquisition. Cambridge, UK: Cambridge University Press.

Oxford, R. L. (1990). Language learning strategies: What every teacher should know. Boston, MA: Heinle \& Heinle.

Oxford, R. L. (2011). Teaching and researching language learning strategies. London, UK: Pearson Education.

Rhoden, S., Ralston, R., \& Ineson, E. (2008). Cabin crew training to control disruptive airline passenger behavior: A cause for tourism concern? Tourism Management, 29(3), 538-547.

Richards,J. (2006). Communicative language teaching today. Cambridge, UK: Cambridge University Press. 
Sánchez Luján, A. F. (2013). The influence of self-monitoring on vocabulary learning and self-efficacy in an A1 teenage group of Colombian state school students (Unpublished Master's thesis). Universidad de La Sabana, Chía, Colombia. Retrieved from http://hdl.handle.net/10818/8299

Sánchez Luján, D. K. (2012). The effect of self-monitoring and selfreflection in $A 1$ adult learners in an English blended learning environment (Unpublished Master's thesis). Universidad de La Sabana, Chía, Colombia. Retrieved from http://hdl.handle. net/10818/3161

Scarcella, R. C., \& Oxford, R. L. (1992). The Tapestry of Language Learning: The individual in the communicative classroom. Boston, MA: Heinle \& Heinle.

Schunk, D. H. (2002). Self-regulation through goal-setting. Retrieved from ERIC database. (ED462671).

Tajima, A. (2003). Use of second language and aviation safety: Analysis offatal miscommunication and attempts for prevention. San Diego, CA: International Communication Association.

Judge,J.W. (2012). Use oflanguage learning strategies by Spanish adults for Business English. International Journal of English Studies, 12(1), 37-54. http://dx.doi.org/10.6018/ijes.12.1.117951

Willis, J. (1996). A framework for task-based learning. Harlow, UK: Longman.

Wood, D. (2009). Preparing ESP learners for workplace placement. ELT Journal, 63(4), 323-331.

Zimmerman, B. J. (2002). Becoming a self-regulated learner. Theory into Practice, 41(2), 64-70. 


\section{APPENDIX: RESEARCH DESIGN AND PEDAGOGICAL IMPLEMENTATION}

\begin{tabular}{|c|c|c|c|c|}
\hline STAGE & INSTRUMENT & PURPOSE & TOPICS/LANGUAGE & DATE \\
\hline \multirow{3}{*}{$\begin{array}{l}\text { Piloting Stage } \\
\begin{array}{l}\text { 16-18 Sept } \\
2013 \\
\text { (3 sessions) }\end{array}\end{array}$} & $\begin{array}{l}\text { Students' } \\
\text { questionnaire (Cohen } \\
\text { et. al., 2007) }\end{array}$ & $\begin{array}{l}\text { Refinements and changes to } \\
\text { questionnaire layout. }\end{array}$ & Does not apply & \multirow{3}{*}{ Sep 16-18 } \\
\hline & $\begin{array}{l}\text { Students' Self- } \\
\text { reflection sheets } \\
\text { (Burns, 2010) }\end{array}$ & $\begin{array}{l}\text { Students worked with the first } \\
\text { version of the self-reflection sheet, } \\
\text { which lead to some adjustments }\end{array}$ & Does not apply & \\
\hline & $\begin{array}{l}\text { Teacher's field notes } \\
\text { (Burns, 2010; Cohen } \\
\text { et. al., 2007) }\end{array}$ & $\begin{array}{l}\text { Recording quick notes about specific } \\
\text { moments in the class. After an } \\
\text { evaluation, the format was changed } \\
\text { to the final version. }\end{array}$ & Does not apply & \\
\hline \multirow{4}{*}{$\begin{array}{l}\text { Data Collection } \\
\text { Stage } 1 \\
23-30 \text { Sept } \\
2013 \\
\text { (4 sessions) }\end{array}$} & $\begin{array}{l}\text { Questionnaire \#1 } \\
\text { (Cohen et. al., 2007) }\end{array}$ & $\begin{array}{l}\text { Initial information of students' } \\
\text { feelings, perceptions of their } \\
\text { learning process, goal-setting and } \\
\text { reflection. }\end{array}$ & $\begin{array}{c}\text { Foods and drinks (1): } \\
\text { Vocabulary. }\end{array}$ & Sep 23 \\
\hline & $\begin{array}{l}\text { Self-reflection sheets } \\
\quad \text { (Burns, 2010) }\end{array}$ & $\begin{array}{l}\text { Students' reflective writings on their } \\
\text { learning process (goals, what they } \\
\text { learned/improved, difficulties, and a } \\
\text { reflection/ action plan) }\end{array}$ & $\begin{array}{l}\text { Foods and drinks (3): } \\
\text { Offering meals. }\end{array}$ & Sep 23,24 \\
\hline & \multirow{2}{*}{$\begin{array}{l}\text { Field notes } \\
\text { (Burns, 2010; Cohen } \\
\text { et. al., 2007) }\end{array}$} & \multirow{2}{*}{$\begin{array}{l}\text { Quick notes, in real time, about } \\
\text { learners' final speaking tasks in } \\
\text { order to discern ongoing behavior } \\
\text { and learners' target language } \\
\text { development as it occurred. }\end{array}$} & $\begin{array}{l}\text { Foods and drinks (3): } \\
\text { Offering meals. }\end{array}$ & \multirow[b]{2}{*}{ Sep 25,30} \\
\hline & & & $\begin{array}{l}\text { Foods and drinks (4): } \\
\text { Problems with food } \\
\text { orders. Apologizing }\end{array}$ & \\
\hline \multirow{4}{*}{$\begin{array}{l}\text { Data Collection } \\
\text { Stage } 2 \\
5-13 \text { Nov } 2013 \\
\text { (4 sessions) }\end{array}$} & $\begin{array}{l}\text { Questionnaire \# } 2 \\
\text { (Cohen et. al., 2007) }\end{array}$ & $\begin{array}{l}\text { Survey information of students' } \\
\text { feelings, perceptions of the } \\
\text { implementation of goal-setting and } \\
\text { reflection. }\end{array}$ & $\begin{array}{l}\text { Boarding (1) } \\
\text { Emergency Exits/ } \\
\text { Row 12. Providing } \\
\text { information, } \\
\text { persuading, giving } \\
\text { directions. }\end{array}$ & Nov 5 \\
\hline & \multirow{2}{*}{$\begin{array}{l}\text { Self-reflection sheets } \\
\quad \text { (Burns, 2010) }\end{array}$} & \multirow{2}{*}{$\begin{array}{l}\text { After re-training, a third set of self- } \\
\text { reflection sheets was gathered, } \\
\text { evidencing learner's goal-setting and } \\
\text { reflection. }\end{array}$} & $\begin{array}{c}\text { Boarding (2) Double } \\
\text { seat assignment/ } \\
\text { oversized baggage. }\end{array}$ & Nov 6,12 \\
\hline & & & $\begin{array}{l}\text { Boarding (3) Briefing } \\
\text { unaccompanied } \\
\text { minors. }\end{array}$ & \\
\hline & $\begin{array}{l}\text { Field notes } \\
\text { (Burns, 2010; Cohen } \\
\text { et. al., 2007) }\end{array}$ & $\begin{array}{c}\text { Live notes about the final speaking } \\
\text { task in order to discern on-going } \\
\text { behavior and learners' target } \\
\text { language development. }\end{array}$ & $\begin{array}{l}\text { Take-off: Safety } \\
\text { requests. Polite } \\
\text { requests, direct } \\
\text { requests }\end{array}$ & Nov 13 \\
\hline \multirow{5}{*}{$\begin{array}{l}\text { Data Collection } \\
\text { Stage } 3 \\
18-23 \text { Nov } \\
2013 \\
\text { (5 sessions) }\end{array}$} & \multirow{2}{*}{$\begin{array}{l}\text { Final questionnaire } \\
\text { (Cohen et. al., 2007) }\end{array}$} & \multirow{2}{*}{$\begin{array}{l}\text { Last survey of students' feelings, } \\
\text { perceptions of the implementation } \\
\text { of goal-setting and reflection about } \\
\text { their language learning process. }\end{array}$} & $\begin{array}{l}\text { Entertainment zone: } \\
\text { Directions and } \\
\text { information }\end{array}$ & \multirow{5}{*}{$\begin{array}{l}\text { Nov } 18 \\
19,20,25 \\
26\end{array}$} \\
\hline & & & $\begin{array}{l}\text { Products and } \\
\text { services. Giving } \\
\text { directions, providing } \\
\text { information }\end{array}$ & \\
\hline & \multirow{2}{*}{$\begin{array}{l}\text { Self-reflection sheets } \\
\quad \text { (Burns, 2010) }\end{array}$} & \multirow{2}{*}{$\begin{array}{l}\text { Final set of self-reflection sheets, } \\
\text { evidencing learner's goal-setting and } \\
\text { reflection processes }\end{array}$} & $\begin{array}{l}\text { Products and } \\
\text { services. Giving } \\
\text { directions, providing } \\
\text { information }\end{array}$ & \\
\hline & & & $\begin{array}{c}\text { Products and } \\
\text { services. Giving } \\
\text { directions, providing }\end{array}$ & \\
\hline & Voice recordings & $\begin{array}{l}\text { Information of learners' actual } \\
\text { oral production and language } \\
\text { development. }\end{array}$ & FINAL EXAM & \\
\hline
\end{tabular}

